\title{
COMPARISONS OF COUNTERFACTUAL AFFIRMATIVE ACTION POLICIES AT THE FEDERAL UNIVERSITY OF MINAS GERAIS
}

\author{
André Braz Golgher (1) (D) \\ E-mail: agolgher@cedeplar.ufmg.br \\ (1) Universidade Federal de Minas Gerais (UFMG), Cedeplar/UFMG, Belo Horizonte - MG, Brasil.
}

DOI: $10.1590 / 3610508 / 2020$

\section{Introduction}

Tertiary education attendance in Brazil varies remarkably among different population groups (Pedrosa et al., 2007). Household income, parents' educational attainment, and race are among the most decisive factors that impact the student's probability of attending an institution of higher education (Pedrosa et al., 2007; Silva and Hasenbalg, 2002).

In order to increase the proportion of Black/Pardo/Indigenous students and of students from low-income families in public universities in Brazil, many institutions of higher education in this country have implemented affirmative action policies since the 2000s. More specifically, the Federal University of Minas Gerais (UFMG) implemented a bonus policy between the years of 2009 and 2012 (Aranha, 2009).

Artigo recebido em: 09/04/2019

Aprovado em: 09/03/2020
In 2012 the national federal law mandating quotas was passed. This law was implemented in all federal institutions of higher education over the following four years (Telles and Paixão, 2013). Since 2016, at least half of the freshmen in all federal universities in Brazil, and therefore also in UFMG, must have studied in public institutions at the secondary level. Consequently, there was a noteworthy increase in the proportion of students from public secondary schools and from low-income households attending public institutions of higher education in Brazil (Francis and Tannuri-Pianto, 2012; Kleinke, 2006; Pedrosa et al., 2007; Telles and Paixão, 2013).

The main objectives of both types of affirmative action policies, bonus and quota policies, are to reduce inequalities in the proportion of racial minorities at public institutions of higher education, to address historical injustices, and to raise diversity on campuses (Francis and Tannuri-Pianto, 2012). Nonetheless, affirmative action policies are often questioned on 
the grounds that they may lower academic standards, as individuals benefited by them might not have a similar academic background as other students (Pedrosa et al., 2007).

Likewise, the main objective of this paper is to analyze different counterfactual affirmative action policies at UFMG. The metrics for evaluating the different possibilities of such policies are based on the proportion of minorities attending this institution and on the average academic performance at this institution. Initially, the paper builds indexes for the diversity of the students who would attend UFMG if different counterfactual affirmative action policies were implemented. The indexes are a function of the student body distributions by race, income, and type of secondary school attended. Indexes based on academic performance in the university, measured by the estimated Grade Point Average - GPA in different semesters, are also built for these different counterfactual policies. Finally, using the indexes for the proportion of minorities that would attend UFMG and for the average estimated GPA, socially optimum indexes are estimated for each of the counterfactual policies.

Twenty-four different policies are compared: a no-policy scenario, eleven bonus policies, and twelve quota policies. The current policy sets a quota of $50 \%$ for students from public secondary schools, divided into four groups (non-poor/non-minority; poor/non-minority; non-poor/minority; poor/ minority). Some policies were better than the current policy at decreasing inequalities in the access of different groups to a high-quality public institution of higher education, while others showed higher levels of average academic performance. The results indicated that policies different from the current one could be implemented, depending on the main objective of the affirmative action policy.

The paper uses official records of UFMG developed by the Permanent Commission of the Vestibular (COPEVE) and by the Department of Academic Registry (DRCA) for those who registered at UFMG in 2012. The databases were kindly made available for research purposes, and the anonymity of the students was preserved.

Many other authors have addressed questions related to affirmative action policies in higher education institutions in Brazil. For instance, Guarnieri and Melo-Silva (2017) made a systematic review of publications that addressed quota policies in Brazil between 2003 and 2013, and Queiroz et al. (2015) described many studies that focused on these topics empirically. However, to the best of my knowledge, this is the first attempt to deal with these issues through policy-oriented analysis of counterfactual affirmative action policy simulations based on real Brazilian data.

The paper is further divided into four sections. The next section presents a literature review, followed by the methodology description, than a presentation of empirical results, and, at last, the paper conclusion.

\section{Literature review}

Many studies analyzed the effects of affirmative action policies, and Holzer and Neumark (2006) presented a lengthy review of the pros and cons of such policies. According to these authors, supporters of affirmative action policies argue that they are necessary to overcome systematic barriers faced by minorities in pursuing higher levels of education. Moreover, they usually consider that these policies increase equitability with little or no loss of efficiency. Conversely, critics of affirmative action commonly claim that discrimination plays a relatively small role nowadays in the determination of educational differentials between race and income groups. Instead, they argue, differences in early family and school environments are the leading causes of the observed educational attainment differences across population groups. Besides, they argue that affirmative action may be highly inefficient, as graduation rates or academic performances of minority students might be lower than those of students from other groups. Moreover, these policies can be potentially harmful to the beneficiaries, in particular, due to the lack of essential academic skills required for college coursework or the potential mismatch between abilities and course demands. However, according to Holzer and Neumark (2006), the combined results of empirical studies support the notion that affirmative action policies at institutions of higher education cause no harm to, and probably some gains in, graduation 
rates for minorities, contrary to the prediction of the mismatch theory.

Concerning the pros, Rothstein (2004) emphasized that exam scores tend to disadvantage lower-income and minority students. Thus, the use of affirmative action policies would overcome some of the limitations of using exams such as the ACT and SAT as the only tools for student selection. Epple et al. (2008) empirically addressed the pros and cons of affirmative action policies. They developed a theoretical model and a computational simulation to provide evidence of the quantitative effects of a ban on affirmative action based on race. They concluded that a ban on this type of policy would have a substantial impact on the racial composition of colleges, particularly on the more competitive ones. The authors believed that this would have negative impacts since they considered that the racial diversity of the student body produces educational benefits, as it promotes cross-racial understanding and the breakdown of stereotypes.

In particular, for the Brazilian reality, the concept of democracy is fundamental to understanding the context in which the discussion about affirmative action policies arose. These policies are based on the notion that all citizens should be guaranteed their social rights, including the possibility of pursuing higher degrees of education, as many individuals in Brazil were and are excluded from tertiary education institutions due to discrimination and lack of opportunities (Queiroz et al., 2015). Therefore, supporters of affirmative action policies state that such policies are, among other things, a social right. Besides, they argue that the remarkable increase in the proportion of students who are Black/Pardo/Indigenous, or who come from public secondary schools and from low-income households, attending public higher education institutions in Brazil (Francis and Tannuri-Pianto, 2012; Kleinke, 2006; Pedrosa et al., 2007; Queiroz et al., 2015; Telles and Paixão, 2013) is a clear indicator of the successfulness of these policies.

Conversely, a frequently raised argument against affirmative action policies is that they may decrease academic standards, particularly in more competitive courses, that is, in courses that require higher marks in the student's entrance exam, as individuals benefited by these policies might not have the same academic background as other students (Pedrosa et al., 2007). Besides, these policies may present other problems (Guarnieri and Melo-Silva, 2017; Jaccoud and Beghin, 2002): they raise the possibility of manipulation of self-declared skin color; they are not in accord with the principle of isonomy; they distract from the real problem of poverty; they concentrate on racial issues, possibly increasing racism; and they do not consider the history of racial blending in the Brazilian population. Moreover, it may not be appropriate to try to overcome the deficiencies in primary schooling at the university level (Freitas, 2006).

According to Guarnieri and Melo-Silva (2017) and Telles and Paixão (2013), although there is some opposition to any affirmative action, the class criterion, which has as a proxy the attendance in public schools, is usually accepted. Racial quotas, however, continue to be more controversial in Brazil, although the necessity to compensate for the historical disadvantage faced by Blacks, Pardos, and the Indigenous in their path to institutions of higher education justifies this type of policy.

Recently, also as a consequence of affirmative action policies, there has been an emergence of racial awareness in Brazil, promoting further and more in-depth discussions about race at a level never accomplished before in Brazil (Guimarães, 2010; Telles and Paixão, 2013). According to Guarnieri and Melo-Silva (2017), the implementation of affirmative action policies is an initial step toward ethnic and racial inclusion and the empowerment of minorities.

Likewise, according to Tosta and Alves (2013), in order to better address questions associated with Black/Pardo and Indigenous students and education, the researcher should not directly associate non-White individuals with poverty and low schooling standards. Moreover, non-Whites, who eventually become highly educated, should not be considered as having a "white soul" or being "white non-Whites," but as possessing a particular non-White identity.

Political, cultural, and social processes build identities through social relationships. The individual's identity is linked to social classes, social groups and communities, and the multitude of interactions 
between social subjects and societies. Therefore, ethnic and racial identities are built based on historical and cultural perspectives. Subjects recognize themselves as members of particular social groups and react accordingly to external experiences. In particular for non-White individuals, the construction, deconstruction, and reconstruction of ethnic and racial identities determine self-representations and relationships not only when pursuing higher levels of education and better positions in the labor market, but also while connecting to spheres where ethnic and racial values are valued, such as Black/Pardo movements. In this process, there is an awareness of the particularities of the Black/Pardo cultures and Black/Pardo pride that was wrecked by the racist structure of Brazilian society (Tosta and Alves, 2013).

Against this historical, cultural and sociological background, bonus policies and quotas have as their primary objective to mitigate social disparities in attendance at public institutions of higher education, and they constitute an intervention against processes that sustain inequalities in Brazil. Besides, the increase in minorities' attendance at institutions of higher education affects labor market outcomes and social mobility (Guarnieri and Melo-Silva, 2017; Siman, 2005), impacting on the construction, deconstruction, and reconstruction of identities.

Although they have similar final objectives, bonus and quota policies differ in some respects. In a quota system, a certain proportion of available spots are reserved for minorities. The bonus policy gives minority students additional points that are proportional to their performance. The bonus policy has some advantages over quota policy (Pedrosa et al., 2007); however, this type of policy does not guarantee a minimum proportion of individuals from minorities in each course. Hence, minorities may be underrepresented in more competitive courses, as observed at UFMG by Golgher et al. (2014, 2015). Therefore, both policies have advantages and disadvantages when compared to each other.

Many studies discussed affirmative action policies using Brazilian data. Guarnieri and Melo-Silva (2017) made a systematic review of publications that addressed quota policies in Brazil between 2003 and 2013. Many of these publications focused on legal and theoretical debates addressing themes such as philosophical, theoretical, and historical issues concerning the implementation of quota policies. Moreover, studies evaluating the impacts and challenges of quota policies were also common. Queiroz et al. (2015) described many studies that empirically analyzed the consequences of quota policies at public universities in Brazil.

Concerning the equalization of opportunities, many studies described the effects of affirmative action policies on the heterogeneity of the student body. Piotto and Nogueira (2016) studied the effects of a bonus policy created in 2006 at the State University of São Paulo (USP). They observed that the proportion of students from secondary public schools and low-income families attending the university increased. However, this same tendency was not observed for individuals whose fathers had low educational attainment. This indicated that the policy helped individuals to overcome some of the difficulties imposed by low socioeconomic status (SES), but was ineffective in helping students to overcome the limited education of their fathers. Francis and Tannuri-Pianto (2012) examined the effects of a quota policy implemented in 2004 at Brasilia University (UnB). They observed that the proportion of Blacks and dark-skinned students in UnB increased, and that displaced applicants were from families of higher SES.

In particular, for UFMG, Aranha et al. (2012) analyzed data for those who applied to and were accepted into UFMG, giving special attention to the effects of the implementation of the bonus policy. These effects were entangled with the increase in the university's slots due to the Reuni policy. Before these policies, the proportion of applicants from secondary public schools had decreased from a slight majority to a large minority. After this policy, the tendency was toward stabilization; nearly $45 \%$ of all applicants were from public secondary schools. Thus, as emphasized by Peixoto and Braga (2012), the implementation of the bonus policy did not remarkably alter the demand for tertiary education among minorities as expected. At UFMG, before the bonus policy was implemented, students from public secondary schools made up around $25 \%$ of the total 
number of selected students. However, they made up a much higher percentage of applicants. After the implementation of the bonus policy, approximately $47 \%$ of those selected by the university came from a secondary public school, a similar number to the proportion who applied. A similar effect was observed for students from households with an income below $500 \%$ of the Brazilian minimum wage (BMW). From this point of view, the policy was rather successful. That is, apparently, these trends are greatly influenced by the bonus policy and less affected by the increase in the number of slots available at UFMG (Aranha et al., 2012; Peixoto and Braga, 2012).

Regarding academic performance at universities in Brazil, Kleinke (2006) observed that beneficiaries of the bonus policy at the State University of Campinas (Unicamp) in 2005 had a higher academic performance than other students in most courses. Velloso (2009) compared the academic performance of students who had and those who had not benefited from a bonus policy in UnB in 2004, 2005, and 2006. In general, both groups showed similar results. However, in more competitive humanities and science courses, the academic performances of beneficiaries of this affirmative action were inferior to those observed for other students. Bezerra and Gurgel (2011) studied some of the effects of quota policies at the State University of Rio de Janeiro (UERJ) in 2005 and 2006. They observed that the academic performance of those benefited by this affirmative action policy was similar to that of other students. Mendes Junior (2014) analyzed the consequences of a quota policy in UERJ between 2003 and 2012 and observed that individuals selected by quotas had a higher GPA than other students. Peixoto et al. (2016) analyzed academic performance differentials at the Federal University of Bahia (UFBA). They observed that students who were not beneficiaries of the quota policy generally had a better academic performance, particularly in courses that were more competitive and in courses that demanded a better background in mathematics.

Conversely, those benefited by the quota policy had a better performance in non-competitive courses in the arts and humanities. Queiroz et al. (2015) observed statistically insignificant differences between beneficiaries and non-beneficiaries of a quota policy at the Federal University of Uberlândia (UFU) for 2013 data. Cavalcanti et al. (2019) analyzed whether beneficiaries and non-beneficiaries of a quota policy had different academic performances using propensity score matching at UFBA between 2005 and 2013. They observed that the first group had lower performances, but this difference was most remarkable at the beginning of the courses.

In particular, for UFMG, Golgher et al. (2014, 2015) studied the differences in academic performance for those who had benefited from the bonus policy and those who had not. Differences were not statistically significant in general. This same result was observed for courses with different levels of competitiveness. The authors concluded that the bonus policy resulted in higher proportions of minorities attending tertiary education without resulting in a loss in academic excellence. However, only a small minority of students favored by this affirmative action policy were selected for more competitive courses, a problem that does not exist with quotas.

This paper addresses the points described above, such as the diversity of the student body and differences in academic performance between students who do and do not benefit from affirmative action policies. However, as the empirical analysis of the paper will make clear, the question it addresses is not whether affirmative action policies should be implemented, but whether the current policy used to select students in the Brazilian public universities could or should be changed for another. The paper describes the effects of counterfactual affirmative action policy simulations on two aspects: the heterogeneity of the student body regarding race, household income, and the attendance of secondary public schools; and academic performance in different semesters, measured by estimated GPA. By doing so, this paper suggests which policies, out of 11 bonus policies and 12 quota policies, optimize student diversity, optimize academic performance, and achieve a socially optimum function. Thus, although this paper addresses topics that have already been discussed, its objectives, approach, and methodology are different from those of previous studies. Moreover, this study has direct and clear policy implications. The next section details the methodology used in this paper. 


\section{Methodology}

Five subsections compose the methodological section of this paper. The first describes the central affirmative action policies implemented as part of UFMG's selection process between 2009 and 2016. The second subsection presents the database. The third details the counterfactual simulations. The fourth subsection describes the methodology used to estimate the GPA. The last subsection presents the methodology used to evaluate the counterfactual policies.

\section{Policies implemented at UFMG between 2009 and 2016}

Table 1 presents the main changes that occurred in the selection process at UFMG between 2009 and 2016. Aranha et al. (2012) described some of these policies in detail.

UFMG implemented a bonus policy in the entrance exam of 2009. This policy increased by $10 \%$ the grades obtained in the entrance exam by individuals who had attended public schools in the last seven years of elementary and secondary education. Also, those who considered themselves Black/Pardo/Indigenous received an extra 5\% bonus. This policy, with minor changes, remained valid until the entrance exam of 2012.

In 2012 the national federal law of quotas was passed and required to be implemented at all federal institutions of higher education over four years (Telles and Paixão, 2013). Beginning with the entrance exam of 2013 , at least $12.5 \%$ of the students in each course had to have done all their secondary schooling at a public institution. This number increased to $25 \%$, $37.5 \%$, and $50 \%$, respectively, in the years 2014 , 2015, and 2016.

Those benefited by the quota policy are further divided into four groups that compete for slots in public higher education institutions: those who lived in a household with per capita income below 150\% of the Brazilian minimum wage (BMW) and who self-declared being Black/Pardo/Indigenous; those who lived in a household with per capita income below 150\% BMW and who did not self-declare being Black/Pardo/Indigenous; those who lived in a household with per capita income equal to or above $150 \% \mathrm{BMW}$ and who self-declared being Black/Pardo/Indigenous; and those who lived in a household with per capita income equal to or above $150 \%$ BMW and who did not self-declare being Black/Pardo/Indigenous.

UFMG also implemented other policies during this period. There was a remarkable increase in the number of slots between 2008 and 2012, mostly due to the Reuni policy (Aranha et al., 2012; Lima and Machado, 2016). Moreover, there have been two changes in the entrance exam since 2009. Until 2010, there was a UFMG exam in two stages. From 2011 to 2013, the ENEM was used as the first stage, while there was a UFMG exam for the second stage. Since 2014 the ENEM has been used as the sole method of student selection (Lima and Machado, 2016).

Table 1

Student Selection Policies at UFMG Between 2009 and 2013

\begin{tabular}{|c|c|c|c|}
\hline Year & Exam for selection & Slots & Affirmative action policy \\
\hline 2009 & \multirow{2}{*}{ UFMG exam at both stages } & \multirow{2}{*}{ Increased remarkably } & \multirow{4}{*}{ Bonus policy: 10\%/15\% } \\
\hline 2010 & & & \\
\hline 2011 & \multirow{3}{*}{$\begin{array}{l}\text { ENEM at the first stage and } \\
\text { UFMG exam at the second }\end{array}$} & \multirow{6}{*}{ Approximately constant } & \\
\hline 2012 & & & \\
\hline 2013 & & & Quota policy: $12.5 \%$ \\
\hline 2014 & \multirow{3}{*}{ ENEM as the sole stage } & & Quota policy: $25 \%$ \\
\hline 2015 & & & Quota policy: $37.5 \%$ \\
\hline 2016 & & & Quota policy: 50\% \\
\hline
\end{tabular}

Source: Aranha et al. (2012). 


\section{Databases}

The paper uses as its database the official records of UFMG that were developed by the Permanent Commission of the Vestibular (COPEVE) and by the Department of Academic Registry (DRCA). The databases were kindly made available for research purposes, and it preserves the anonymity of the students.

The databases with data on students who applied to UFMG between 2009 and 2013 include the results of the entrance exams and the GPA in specific semesters of all the students who applied for UFMG. Moreover, they contain socioeconomic variables and information regarding affirmative action policies, as will be detailed in subsection 3.4. Other studies (Golgher et al., 2014, 2015) use these or similar databases; however, these analyses had different approaches and objectives.

The primary purpose of this paper is to evaluate different affirmative action policies. Thus, as detailed in Table 1, since UFMG's selection process nowadays is based on the ENEM exam, the simulations were done with the results of this exam. Accordingly, the databases with the students who applied to UFMG in 2012 and 2013 could be used to do the simulations, as the selection process used the ENEM. Moreover, most of the increase in the number of slots had already taken place in this period, and the results of this paper represent a similar reality to that of the most recent years. However, the database for 2013 has GPA information only for first-year students. Therefore, this paper uses the data from 2012, which had results for freshmen and for sophomores, in order to determine whether minority students catch up while in the university. That is, the counterfactual affirmative action policies described in the next section are applied to those students who applied to the university in 2012; however, conditions have not changed much since then, except for the affirmative action policies which are simulated here.

\section{Counterfactual Policies}

There are some possibilities of analysis regarding affirmative action policies at UFMG. The main questions being addressed are: 1) Which affirmative action optimizes the diversity of the student body?; 2) Which affirmative action optimizes academic performance?; 3) Taking into account the potential trade-off between the increased representation of minorities and academic performance, which would be the optimum policy?; 4) Bonus and quota policies differ in many aspects, which would be the optimum policy for each objective?

These are the main questions being empirically addressed by this paper with the use of simulations for different counterfactual affirmative action policies. As mentioned, the UFMG's selection process nowadays is based on the ENEM exam, so the simulations were done with the results of this exam. This exam is composed of five tests: composition, mathematics, language, humanities, and science. However, the results for composition were available only for those classified in the first stage of the selection process. Thus, in order not to lose the majority of the observations and to include all applicants for a slot at UFMG in 2012, the simulations were done with the sum of the results of the other four exams.

The paper describes 24 simulations, including a scenario with no affirmative action policy as well as 11 bonus policies and 12 quota policies. The first simulation is the one without any affirmative action policy (policy 1). The number of slots in each course is fixed. The best results for the sum of the four ENEM exams were considered in the simulations until this fixed number was achieved in each course.

The second simulation is the policy in use from 2009 to 2012, but adapted to the ENEM results, which show less variability than UFMG's exam. Therefore, instead of using bonuses of $10 \%$ and $15 \%$, the values were respectively $5 \%$ and $7 \%$ (policy 2 ; bonus 1 ).

The other bonus policies can be divided into three groups. The first group proposed an equal bonus for all students who had applied for the bonus policy in 2012, irrespective of skin color/ethnic group, with increasing value for the bonus: $6.5 \%$, $8 \%, 10 \%$, and $12 \%$ (policies $3-6$; bonus $2-5$ ). The other group of bonus policies increased the grades of those who had studied in public schools throughout the secondary level with a linear function of the minimum score required to be selected by the university. This policy takes into account the fact that, 
even with a bonus, students from public schools tend to be underrepresented in more competitive courses (Golgher et al. 2014, 2015). Therefore this type of policy tries to overcome some of this limitation by increasing the bonus for more competitive courses. (Other functions were also used, but the results of the linear function were considered satisfactory, and this makes the policy easier to understand for the population in general).

Moreover, this policy is easy to implement if based on the results of the selection process of the previous year. Three policies based on the linear function are proposed with respective average bonus values of $6 \%$, $8 \%$, and 10\% (policies 7 - 9; bonus 6-8). Another proposed group of bonus policies increased the grades obtained in the entrance exam as a function of the amount of time the student attended public schools at the elementary and secondary levels, from 0 to 11 years. However, some students may have studied the first years of the elementary level in public schools, while others may have studied their final years of secondary education in public schools. Hence, the grades in which the student studied in private or public institutions matter. Thus, two variables were used to determine this bonus policy: the amount of time the students studied in public institutions, and whether the secondary level was done in public or private schools. Three policies were designed respectively, with average bonuses of $5.8 \%$, $7.3 \%$, and $8.7 \%$ for students who attended a public school at the elementary or/and at the secondary level. Table 2 shows the bonuses for each of these policies for the different groups of students. Those who had studied all their basic education, eight years of elementary school plus three years of secondary education, in public schools were granted respectively $12 \%, 15 \%$, or $18 \%$, depending on the average bonus. Those who had zero years of public education had no bonus. The other possibilities had intermediate values depending on the amount of time spent in public institutions and on whether the secondary level was attended in a public institution, defined as multiples of the maximum bonus divided by six (policies $10-12$; bonus 9 - 11).

Four other groups of simulations were done for quotas. Each group contains three policies, respectively, with a minimum of $40 \%, 50 \%$, or $60 \%$ of students from secondary public schools in each course. They differ in how the students of public schools were further classified, as shown in Table 3. Quota policy group 1 does not further classify the students from public schools. Policy group 2 divides them by race, and policy group 3 divides them by household income. The last policy group is similar to the one currently being applied in Brazil and divides the students into four categories by race and household income (policies 13-24; quota 1 -12).

\section{Estimated GPA}

Each of the policies mentioned above was evaluated on two aspects which are related respectively, to equity and efficiency, but which do not encompass the totality

Table 2

Bonuses Based on the Time Spent in Public Institutions

\begin{tabular}{|c|c|c|c|c|}
\hline & & \multicolumn{3}{|c|}{ Bonus (\%) } \\
\hline & & Policy 1 & Policy 2 & Policy 3 \\
\hline \multicolumn{2}{|c|}{ Mean value } & 5.8 & 7.3 & 8.7 \\
\hline $\begin{array}{c}\text { Time spent in public } \\
\text { institutions }\end{array}$ & $\begin{array}{c}\text { Type of secondary } \\
\text { school diploma }\end{array}$ & & & \\
\hline 0 & \multirow{4}{*}{ Private } & 0 & 0 & 0 \\
\hline $1-3$ & & 2 & 2.5 & 3 \\
\hline $4-7$ & & 4 & 5 & 6 \\
\hline $8-11$ & & 6 & 7.5 & 9 \\
\hline $0-3$ & \multirow{4}{*}{ Public } & 6 & 7.5 & 9 \\
\hline $4-7$ & & 8 & 10 & 12 \\
\hline $8-10$ & & 10 & 12.5 & 15 \\
\hline 11 & & 12 & 15 & 18 \\
\hline
\end{tabular}


Table 3

Quota Policies

\begin{tabular}{ccc}
\hline $\begin{array}{c}\text { Quota Policy } \\
\text { group }\end{array}$ & $\begin{array}{c}\text { Students from } \\
\text { private secondary } \\
\text { schools }\end{array}$ & Students from public secondary schools \\
\hline 1 & All & All \\
\hline 2 & All & Black/Pardo/Indigenous; White/Asian \\
\hline 3 & All & From low-income households; From high-income households \\
\hline 4 & All & $\begin{array}{c}\text { Black/Pardo/Indigenous from low-income households; Black/Pardo/Indigenous } \\
\text { from high-income households; White/Asian from low-income households; } \\
\text { White/Asian from-high income households; }\end{array}$ \\
\hline
\end{tabular}

of the concepts: the distribution of minorities in the student body, and academic performance. Concerning the first concept, two terms are commonly used when addressing inequalities at higher education institutions: equitable and accessible (Astin and Oseguera, 2004). Education equity is directly related to the accessibility of these institutions, although it is also associated with equitability, and consequently, with fairness. This paper narrowly assesses the concept of equitability and accessibility by considering the proportion of minorities at UFMG.

Similarly, efficiency is a multidimensional concept, and academic performance is only one of its dimensions. Efficiency may also be assessed, among other measures, by graduation and dropout rates (Holzer and Neumark, 2006). Higher dropout rates at institutions of higher education result in economic waste associated with non-graduation. Besides, individuals who drop out may be adversely affected by a sense of failure (Vignoles and Powdthavee, 2009). This paper evaluates just the concept of efficiency through the lens of one of its dimensions: academic performance. Concerning this last point, the variable of interest is the GPA in a specific semester for students who entered UFMG in 2012. There was complete data available for the first three semesters, and we selected the first and the third semesters in order to observe possible catching-up of minority students during their time at the university.

The empirical strategy is inspired by Regression Discontinuity (RD) designs (Lee and Lemieux, 2010). The technique was introduced in 1960 as a way of estimating treatment effects in non-experimental settings where a cutoff defines treatment so that those above the cutoff receive treatment, and those below do not. The main idea of RD is that individuals with scores just below and barely above the cutoff are useful comparisons, as they tend to be similar in aspects other than the treatment, including non-observables. The agent's inability to precisely control the assignment variable leads to a random variation in the treatment. Hence Lee and Lemieux (2010) show that RD design is a much closer cousin of randomized experiments than typical "natural experiment" strategies, such as difference-in-differences or instrumental variables. They also show that causal inferences from $\mathrm{RD}$ designs tend to be more credible than such inferences from "natural experiment" strategies. This technique is widely used in many analyses; for instance, Buddelmeyer and Skoufias (2004) studied programs designed to help impoverished communities, where poverty rates establish the eligibility of a community.

In this paper, those who were not selected by UFMG but were close to the cutoff for being selected may be similar to those who were selected but were just above the cutoff in the entrance exam. The database contained the GPAs of those who were selected and who entered UFMG in 2012. However, the GPAs of those who applied to UFMG but narrowly missed being selected is unknown. Nonetheless, it we assume that they are potentially close to selected students who were close to the cutoff, after controlling for observable variables. These are the students who will change places, from selected to non-selected and vice-versa, in the simulations. Therefore, it was necessary to estimate the GPAs of the students who were not selected by UFMG, but who would have been selected if different affirmative action policies had been implemented. The estimated GPA was obtained for all students and was used to evaluate the simulations. 
For those who applied to UFMG, whether they were selected or not, the database records many socioeconomic and demographic variables, among them many factors that may affect academic performance, such as individual attributes, household characteristics, and school factors (Araújo and Siqueira, 2010; Barros et al., 2001; Soares and Alves, 2013). In particular, for higher education in Brazil, Francis and Tannuri-Pianto (2012) observed that Whites and females had higher academic performances at the university. Golgher et al. $(2014,2015)$ verified that students at UFMG who had studied in a municipal, federal or private secondary school; who had not attended specific courses preparing for the exam of tertiary education institutions (pré-vestibular); who did not work, or who worked up to twenty hours per week; who came from higher incomes household; and who had computers at home had higher performances.

On the same subject, the variables used to estimate GPAs in this paper are the following: the individual's characteristics (sex, race, civil status, workload, whether the individual had already graduated, whether the individual had attended a pré-vestibular, and the individual's place of residence); characteristics of the household (the father's and the mother's schooling level, the household income, and the father's and the mother's occupations); features related to the student's secondary education (years since high school graduation; the regime of the secondary school; and type of secondary school) and assets in the household (domestic servants, fridges, cars, and computers). Most of these variables are commonly used in studies that address the determinants of schooling performance at different levels (Araújo and Siqueira, 2010; Barros et al., 2001; Francis and Tannuri-Pianto, 2012; Golgher et al., 2014, 2015; Soares and Alves, 2013).

Besides the socioeconomic and demographic variables, the database has information on the four exam mentioned above from the ENEM - mathematics, language, humanities, and science. Some authors related academic performance at the tertiary level with performance on the entrance exams of institutions of higher education. Bai and Chi (2011) observed that the Chinese College Entrance Examination score predicted undergraduate GPAs for all four years in college. Loury and Garman (1993) verified that higher SAT scores correlate positively with GPAs for Whites and Blacks. Similarly, Fryer Jr. et al. (2008) observed a positive correlation between SAT scores and college GPAs. Likewise, Bettinger et al. (2013) verified a strong positive correlation between ACT composite scores and college outcomes. Thus, we included the results of four exams from the ENEM in the estimations of GPAs.

Besides, UFMG has dozens of courses, each one with its idiosyncrasies in terms of evaluations. Therefore, grades might differ when similar individuals attend different courses. Hence, in order to capture this feature, a dummy for each course was also included in the models.

More formally, in a similar vein to Bettinger et al. (2013) and Bulman (2017), the GPA was estimated by the following equation:

$$
G \hat{P} A_{i s k}=\alpha_{s}+\delta X_{i}+\sum_{j} \beta_{j} \text { Subject }_{i j}+\gamma D_{k}+\varepsilon_{i s},
$$

where $i$ is individual, $s$ is semester, $k$ is course, $X_{i}$ is a set of controls of $i$ (features of the individual, characteristics of the household, and features related to the student's secondary education), Subject $_{l i j}$ is the performance of $i$ in the subject $j$ in the selection process, $D_{k}$ are the dummies for courses, and $\varepsilon_{i s k}$ are the stochastic errors.

The GPA is continuous and an approximately customarily distributed variable that ranges between 0 and 5 . Academic performance can only vary between 0 and 5 , as the variable is censored in both extremes. Thus, double censored Tobit models were used to estimate GPA instead of OLS models.

\section{Counterfactual policy evaluations}

Affirmative action policies have as their primary objective to decrease inequalities and to increase the proportion of minorities in public universities. However, a frequently raised objection to affirmative action policies is that they may decrease academic standards. Taking into account the potential trade-off between an increase in the proportion of minorities and academic performance, a socially optimum policy may be defined based on both aspects. This 
paper discusses each of these three points separately with indicators.

Initially, we divided the university's courses into 14 groups: medicine, law, social communication, engineering and exact science courses (less competitive), engineering and exact science courses (competitive), engineering courses (more competitive), economic sciences courses (less competitive), economic sciences courses (more competitive), humanities courses (less competitive), humanities courses (more competitive), biological and health sciences courses (less competitive), biological and health sciences courses (more competitive), arts courses (less competitive), and architecture and art courses (more competitive). We weighted all groups by the number of students in each group. That is, the results treated students in less and more competitive courses in different knowledge areas as equals.

\section{Diversity of the student body}

Initially, we evaluated the policies in terms of the diversity of the student body based on the proportion of Black/Pardo/Indigenous students, the proportion of poor individuals, and the proportion of students from public secondary schools who would be selected in UFMG in each of the simulations. We summarized the results with the use of indicators. However, the choice of indicators is necessarily arbitrary; hence the paper describes two of them in order to encompass a diversity of perspectives.

The first indicator, indicator 1 , is defined based on the difference between the proportion of students who would be accepted at UFMG if a particular policy was implemented when compared to the amount who applied in each group of courses. The following expression for race represents it:

$$
I_{\text {race }}=\sum_{i=1}^{14} N_{i}\left|x_{i}-y_{i}^{*}\right| / \sum_{i=1}^{14} N_{i}\left|z_{i}-y_{i}^{*}\right|,
$$

where $x_{i}$ is the proportion of Black/Pardo/Indigenous students at UFMG in each group of courses $i$ when a particular policy is implemented, $y_{i}^{*}$ is the proportion of Black/Pardo/Indigenous students among those who applied to UFMG in the specific group of courses, and $z_{i}$ is the proportion of Black/Pardo/Indigenous students at UFMG in the specific group of courses when no affirmative action policy is implemented.

The following equation represents indicator 1 for income: $I_{\text {income }}=\left(\sum_{i=1}^{14} N_{i}\left(2\left|x_{I i}-y_{I i}{ }^{*}\right|+\left|x_{2 i}-y_{2 i}{ }^{*}\right|\right)\right) /\left(\sum_{i=1}^{14} N_{i}\left(2\left|z_{l i}-y_{I i}{ }^{*}\right|+\left|z_{2 i}-y_{2 i}{ }^{*}\right|\right)\right)$, where $x_{I i}$ is the proportion of students from households with income below 200\% BMW in the group of courses $i$ when a particular policy is implemented, $y_{I i}{ }^{*}$ is the same proportion among those who applied to UFMG in the specific group of courses, $x_{2 i}$ is the proportion of students from households with income between 200\% and 500\% BMW in the group of courses $i$ when a particular policy is implemented, $y_{2 i}{ }^{*}$ is the same proportion among those who applied to UFMG in the specific group of courses, and $z_{l i}$ and $z_{2 i}$ are the same proportions when no affirmative action policy is implemented.

The expression for the proportion of students from public schools is the same as the one used for race. Notice that we compare the three indicators to the simulation with no affirmative action policy. Thus, nearly all results for each indicator are positive numbers smaller than one.

The second indicator, indicator 2 , is similar to the first; however, it is defined based on the difference between the proportion of students accepted at UFMG in each group of courses and the proportion of students who applied to all courses in the university to the same proportion for those who applied to all courses in the university. For example, indicator 1 included $y_{i}^{*}$, the proportion of a variable among those who applied to UFMG in a specific group of courses. Indicator 2 uses the same expression, but instead of $y_{i}{ }^{*}$, it uses $\bar{y}^{*}$,the proportion of a variable among all those who applied to UFMG.

Comparing both indicators, indicator 1 analyses each group of courses separately before aggregating the results. Thus, it is a partial indicator of equality that does not take into account the heterogeneity between the applicants to each group of courses. Indicator 2 includes the heterogeneity of the applicants in the estimates. Therefore, it is more radical than the first, as it tries to overcome not only the unequal probabilities of being selected for a specific group of courses but also the inequalities associated with the heterogeneity of applicants between groups of courses.

Using the above methodology, indicators 1 and 2 give the results for each dimension: race, income, 
and public school attendance. Table 4 in the next section shows the results.

However, an affirmative action policy affects all three dimensions. We created two indexes in order to evaluate the policies. In both, we gave equal weights for each of the three topics. Index A is the mean value of the results of each dimension. Index $B$ is the product of the results in each dimension divided by the results in the respective dimensions of the simulation without an affirmative action policy. Therefore, both indexes vary between zero and one. Table 5 shows the results. Index B can be considered more radical, as a very small value in one dimension decreases more intensively in this index than in Index A

\section{The estimated GPA for each affirmative action policy}

We compare the estimated average GPA resulting from each simulated affirmative action policy to the simulation with no affirmative action. More formally, the following expression represents it:

$$
\Delta G P A_{j}=\sum_{i=1}^{14} N_{i j}\left(G P A_{i j}-G P A_{b i j}\right),
$$

where $i$ is the group of courses, $j$ is the semester (first or third), $N_{i j}$ is the number of students in each group of courses in each semester, $G_{A A_{i j}}$ is the mean GPA for each group of courses under a specific policy, and $G P A_{b i j}$ is the mean GPA for each group of courses for the simulation without a policy.

Table 4

Effectiveness of Counterfactual Affirmative Action Policies in Decreasing Inequalities in the Student Body Concerning Race, Income, and Public School Background (\%)

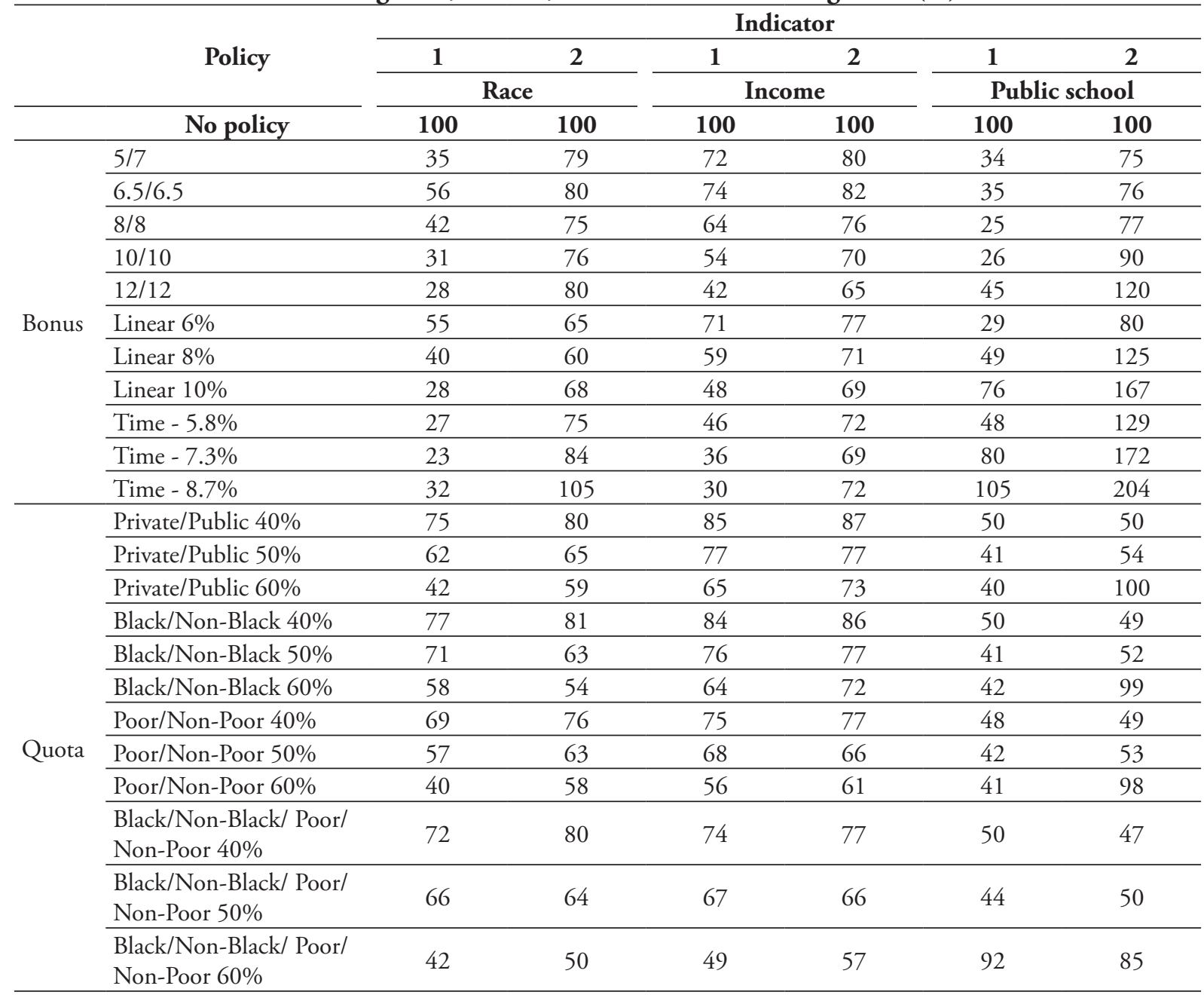


Table 5

Indicators of Effectiveness of Counterfactual Affirmative Action Policies in Decreasing Inequalities in the Student Body (\%)

\begin{tabular}{|c|c|c|c|c|c|c|}
\hline & \multirow{3}{*}{ Policy } & \multicolumn{4}{|c|}{ Indicator } & \multirow{3}{*}{$\begin{array}{l}\text { Mean } \\
\text { ranking }\end{array}$} \\
\hline & & 1 & 1 & 2 & 2 & \\
\hline & & Index A & Index B & Index A & Index B & \\
\hline & No policy & 100 & 100 & 100 & 100 & 23 \\
\hline \multirow{11}{*}{ Bonus } & $5 / 7$ & 47 & 9 & 78 & 48 & 11 \\
\hline & $6.5 / 6.5$ & 55 & 15 & 80 & 50 & 15 \\
\hline & $8 / 8$ & 44 & 7 & 76 & 44 & 9 \\
\hline & $10 / 10$ & 37 & 4 & 78 & 47 & 8 \\
\hline & $12 / 12$ & 38 & 5 & 89 & 63 & 11 \\
\hline & Linear 6\% & 52 & 11 & 74 & 40 & 11 \\
\hline & Linear 8\% & 49 & 12 & 85 & 53 & 14 \\
\hline & Linear $10 \%$ & 51 & 10 & 101 & 79 & 16 \\
\hline & Time - 5.8\% & 40 & 6 & 92 & 70 & 12 \\
\hline & Time - 7.3\% & 46 & 7 & 108 & 99 & 14 \\
\hline & Time $-8.7 \%$ & 56 & 10 & 127 & 153 & 18 \\
\hline \multirow{12}{*}{ Quota } & Private/Public 40\% & 70 & 32 & 72 & 35 & 16 \\
\hline & Private/Public 50\% & 60 & 20 & 65 & 27 & 11 \\
\hline & Private/Public 60\% & 49 & 11 & 77 & 43 & 11 \\
\hline & Black/Non-Black 40\% & 70 & 32 & 72 & 34 & 15 \\
\hline & Black/Non-Black 50\% & 63 & 22 & 64 & 25 & 11 \\
\hline & Black/Non-Black 60\% & 54 & 15 & 75 & 38 & 12 \\
\hline & Poor/Non-Poor $40 \%$ & 64 & 25 & 68 & 29 & 13 \\
\hline & Poor/Non-Poor $50 \%$ & 56 & 16 & 61 & 22 & 8 \\
\hline & Poor/Non-Poor $60 \%$ & 46 & 9 & 73 & 35 & 8 \\
\hline & Black/Non-Black/ Poor/Non-Poor 40\% & 65 & 26 & 68 & 29 & 14 \\
\hline & Black/Non-Black/ Poor/Non-Poor 50\% & 59 & 19 & 60 & 21 & 9 \\
\hline & Black/Non-Black/ Poor/Non-Poor 60\% & 61 & 19 & 64 & 24 & 10 \\
\hline
\end{tabular}

The results are shown in Table 6.

\section{The socially optimum estimates}

As the results for student diversity and for estimated GPA measure two different dimensions with different distributions, we designed a method to aggregate these partial results. A ranking between the 24 simulations was created for indicator 1 and index $\mathrm{A}$, for indicator 1 and index $\mathrm{B}$, for indicator 2 and index $\mathrm{A}$, for indicator 2 and index $\mathrm{B}$, for $\triangle G P A_{1}$ and for $\triangle G P A_{3}$. Thus, we could compare the results in the different dimensions.

Nonetheless, for student diversity, the correlations for indicators 1 and 2 were positive and strong in both indexes. Thus, we initially selected the less and the more radical results: indicator 1 and index $A$, and indicator 2 and index B.

Moreover, for estimated GPA, the correlations between the results for the first and third semesters within each simulation were also positive and strong. Thus, we created an indicator for estimated GPA differences: $\triangle G P A=\triangle G P A_{1}+2 \triangle G P A_{3}$. We gave more weight to differences in GPA in the third semester because they more closely resemble the many semesters in the university than does the first, which is atypical but is essential to define early dropouts.

Finally, which is more critical: the increase in the proportion of minorities or the potential decrease in academic performance? This is necessarily an arbitrary choice. Thus, we created three scenarios. 
Table 6

Comparisons for Differences in Mean Estimated GPA for Different Counterfactual Affirmative Action Policies

\begin{tabular}{|c|c|c|c|c|}
\hline & \multirow{2}{*}{ No policy } & \multirow{2}{*}{$\begin{array}{c}\text { First semester } \\
0 \\
\end{array}$} & \multirow{2}{*}{$\begin{array}{c}\text { Third semester } \\
0\end{array}$} & \multirow{2}{*}{$\frac{\text { Weighted average }}{0}$} \\
\hline & & & & \\
\hline \multirow[t]{11}{*}{ Bonus } & $5 / 7$ & -1.00 & -0.39 & -0.59 \\
\hline & $6.5 / 6.5$ & 0.40 & 0.38 & 0.39 \\
\hline & $8 / 8$ & -0.95 & -0.87 & -0.90 \\
\hline & $10 / 10$ & -1.62 & -1.48 & -1.53 \\
\hline & $12 / 12$ & -2.03 & -1.92 & -1.96 \\
\hline & Linear 6\% & 7.28 & 7.34 & 7.32 \\
\hline & Linear 8\% & -1.25 & -1.21 & -1.22 \\
\hline & Linear $10 \%$ & -1.62 & -1.63 & -1.62 \\
\hline & Time $-5.8 \%$ & -1.62 & -2.13 & -1.96 \\
\hline & Time - 7.3\% & -2.17 & -2.20 & -2.19 \\
\hline & Time - 8.7\% & -2.02 & -1.91 & -1.95 \\
\hline \multirow[t]{12}{*}{ Quota } & Private/Public $40 \%$ & 5.13 & 4.61 & 4.78 \\
\hline & Private/Public 50\% & 0.12 & 0.11 & 0.12 \\
\hline & Private/Public 60\% & -0.67 & -0.42 & -0.51 \\
\hline & Black/Non-Black 40\% & 0.13 & -0.07 & 0.00 \\
\hline & Black/Non-Black 50\% & -0.11 & 0.04 & -0.01 \\
\hline & Black/Non-Black 60\% & -0.75 & -0.38 & -0.51 \\
\hline & Poor/Non-Poor $40 \%$ & 1.20 & 0.60 & 0.80 \\
\hline & Poor/Non-Poor $50 \%$ & 0.20 & 0.04 & 0.09 \\
\hline & Poor/Non-Poor $60 \%$ & -0.52 & -0.09 & -0.23 \\
\hline & Black/Non-Black/ Poor/Non-Poor 40\% & -0.13 & -0.54 & -0.40 \\
\hline & Black/Non-Black/ Poor/Non-Poor 50\% & -0.33 & -0.01 & -0.12 \\
\hline & Black/Non-Black/ Poor/Non-Poor 60\% & -0.61 & -0.14 & -0.30 \\
\hline
\end{tabular}

In the first, diversity is assigned twice as much weight as performance; in the second, both have the same weight; in the third, performance is assigned twice as much weight as diversity. The objective is to show a range of results. These three scenarios were created for both indicators of diversity. The results are shown in Table 7. By drawing different scenarios, we minimize the limitations of arbitrary choices.

\section{Results}

We display the results in three subsections following the presentation of the previous section.

\section{The diversity of the student body}

This subsection presents the results for the proportion of minorities in the student body for the different counterfactual affirmative action policies.
Among the main questions that we empirically address in this paper, we can partially answer two in the following two tables: 1) Which affirmative action optimizes the diversity of the student body?; 2) Bonus and quota policies differ in many aspects, what raises the question about which would be the optimum policy of each type?

Table 4 presents the results for indicators 1 and 2 separately for race, income, and proportion of students who had attended secondary public schools. First, notice that the results are given as a percentage of those observed for the case without any affirmative action policy. The results show that most policies were effective at increasing race diversity in UFMG, as most values are below unity. One policy, providing a bonus based on time spent in public secondary schools with an average bonus of 8.7, actually decreased diversity, as the proportion of Black/Pardo/Indigenous students accepted under this policy was higher than the proportion of Black/Pardo/Indigenous students who had applied to UFMG. 
Table 7

Comparisons for Differences in Socially Optimum Functions for Different Counterfactual Affirmative Action Policies

\begin{tabular}{|c|c|c|c|c|c|c|c|}
\hline & \multirow{3}{*}{ Policy } & \multicolumn{6}{|c|}{ Index/Indicator } \\
\hline & & B2 & A1 & B2 & A1 & B2 & A1 \\
\hline & & \multicolumn{2}{|c|}{ Minorities } & \multicolumn{2}{|c|}{ Equal weights } & \multicolumn{2}{|c|}{$\begin{array}{l}\text { Academic } \\
\text { performance }\end{array}$} \\
\hline \multirow{11}{*}{ Bonus } & $5 / 7$ & 47 & 29 & 47 & 33 & 46 & 37 \\
\hline & $6.5 / 6.5$ & 38 & 30 & 32 & 26 & 25 & 21 \\
\hline & $8 / 8$ & 44 & 24 & 45 & 30 & 46 & 36 \\
\hline & $10 / 10$ & 48 & 20 & 50 & 29 & 51 & 37 \\
\hline & $12 / 12$ & 59 & 25 & 60 & 35 & 61 & 44 \\
\hline & Linear 6\% & 25 & 23 & 20 & 18 & 14 & 13 \\
\hline & Linear $8 \%$ & 53 & 35 & 53 & 39 & 52 & 43 \\
\hline & Linear $10 \%$ & 61 & 39 & 60 & 44 & 59 & 48 \\
\hline & Time $-5.8 \%$ & 62 & 28 & 63 & 38 & 64 & 47 \\
\hline & Time $-7.3 \%$ & 67 & 35 & 68 & 44 & 68 & 52 \\
\hline & Time $-8.7 \%$ & 66 & 50 & 65 & 53 & 63 & 55 \\
\hline \multirow{12}{*}{ Quota } & Private/Public 40\% & 20 & 48 & 17 & 38 & 13 & 27 \\
\hline & Private/Public 50\% & 15 & 39 & 15 & 33 & 15 & 27 \\
\hline & Private/Public 60\% & 40 & 30 & 41 & 33 & 41 & 36 \\
\hline & Black/Non-Black 40\% & 23 & 51 & 23 & 44 & 22 & 36 \\
\hline & Black/Non-Black 50\% & 16 & 46 & 18 & 41 & 20 & 35 \\
\hline & Black/Non-Black 60\% & 35 & 37 & 36 & 38 & 37 & 38 \\
\hline & Poor/Non-Poor $40 \%$ & 15 & 43 & 14 & 35 & 12 & 26 \\
\hline & Poor/Non-Poor $50 \%$ & 10 & 34 & 12 & 30 & 14 & 26 \\
\hline & Poor/Non-Poor $60 \%$ & 30 & 20 & 30 & 23 & 30 & 25 \\
\hline & Black/Non-Black/ Poor/Non-Poor 40\% & 26 & 54 & 29 & 50 & 31 & 45 \\
\hline & Black/Non-Black/ Poor/Non-Poor 50\% & 11 & 41 & 15 & 38 & 19 & 34 \\
\hline & Black/Non-Black/ Poor/Non-Poor $60 \%$ & 17 & 47 & 21 & 44 & 25 & 40 \\
\hline
\end{tabular}

Notice that the values for race for the policy that was previously implemented in UFMG, bonus $5 / 7$, are 35 and 79 , respectively, for indicator 1 and indicator 2 . The same values for the current policy, a quota of $50 \%$ divided between poor, non-poor, non-Black/Pardo/Indigenous, and Black/Pardo/Indigenous students, are 66 and 64. That is, the bonus policy seems better at equalizing the heterogeneity of the race distribution within each of the 14 groups of courses. However, the quota policy is more effective at equalizing the overall distribution among all courses in the university.

Many of the proposed policies were better than one of these two cited policies in equalizing the proportions of Black/Pardo/Indigenous students in one of the indicators. However, no policy was more effective than both policies in both indicators.
Compared to the current policy, some policies were more effective at promoting an equalization of race distribution in both indicators: a linear bonus policy with an average bonus of $8 \%$, any quota of $60 \%$, and a quota of $50 \%$ divided between poor and non-poor. Thus, if the policymaker considers that decreasing racial inequalities is the main focus of affirmative action policy, there are better choices than the current policy: a linear $8 \%$ bonus policy, any $60 \%$ quota policy, or a $50 \%$ quota policy divided between poor and non-poor students.

This same type of analysis is done for income. The current policy seems to be more effective in increasing the proportion of individuals from low-income families than the previous policy in both indicators (67/66 against 72/80). However, a few of the proposed policies were more effective 
than the current policy in both indicators: either a bonu-policy of $12 \%$, or quota policies of $60 \%$, divided between poor and non-poor or divided between poor, non-poor, Black/Pardo/Indigenous, and non-Black/Pardo/Indigenous students.

When we take into account race and income, two policies were better than the current policy in both indicators. Both were quota policies of $60 \%$. One was divided between poor and non-poor students, while the other was divided between poor, non-poor, Black/Pardo/Indigenous, and non- Black/Pardo/Indigenous students.

For the proportion of students from public schools, similar to what we observed for race, the bonus policy previously implemented seems better at equalizing the heterogeneity of the distribution within each of the 14 groups of courses. However, the current quota policy is more effective at equalizing the overall distribution among all courses in the university (34 against 44 and 75 against 50). Notice that many policies increased heterogeneity in this factor when compared to the simulation with no policy, as is observed by the values above 100 percent. These values indicate that, under the proposed policies, there would be a more significant proportion of students from public schools in the pool of accepted students than in the pool of applicants. No policy was more effective than the current one in both indicators.

To summarize, the results from Table 4 indicate that the previous bonus policy is superior in some aspects to the current quota policy. However, in most scenarios, the current policy is more effective in promoting equal representation in the student body. None of the proposed policies is superior to the current policy in all three factors in both indicators. Three policies are more effective in most scenarios: the quota policy of $60 \%$ divided between poor and non-poor students; the quota policy of $60 \%$ divided between Black and non-Black students; and the current quota policy but at $60 \%$. No bonus policy was superior to the current quota policy. However, four of them were superior in half of the scenarios: equal bonuses of $8 \%, 10 \%$ and $12 \%$, and a linear bonus of $8 \%$.

These results suggest that the current quota policy is effective in promoting equalization of opportunities. Another right choice would be the quota policies of $60 \%$.

Given the variability in the results presented in Table 4, we present two indexes in Table 5. One is the mean value of the three factors presented in Table 4, index $A$, and the other is the product of the values of the three factors, index $B$, normalized by the values of the simulation without an affirmative action policy. Concerning these two indexes, the policy previously implemented in UFMG is better for indicator 1 and the current policy is better for indicator 2. The overall picture shows that the current policy is a slight improvement over the previous policy in terms of equal participation in the student body.

Many policies were more effective than the current one for the first indicator for both indexes, but none was superior for the second indicator, also considering both indexes. That is, the current policy was the most effective in promoting equal participation of students from different demographic groups in all courses in the university, although it was not the most effective in promoting equal participation of students from different demographic groups in each group of courses. Thus, from this point of view, the current policy should only be changed if other factors are involved in choosing an affirmative action policy. If promoting equal participation of students from different demographic groups in all courses in the university is what matters most, the current policy is well designed.

The last column of the table includes the average ranking for all the 24 policies in the four possibilities of indicators and indexes. Three had a value inferior to the current policy, though differences are small (8 against 9): a bonus policy of $10 \%$, and quotas of $50 \%$ or $60 \%$ divided between poor and non-poor students.

\section{The estimated GPA}

Table 6 presents the results for the estimated GPA. The no-policy option is the reference. The numbers indicate the difference in mean estimated GPA between the affirmative action policy and the reference multiplied by 100 . For instance, the current policy had the values -0.33 for the first semester and 
-0.01 for the third. These numbers indicate that the mean estimated GPA for the first semester with the policy was $0.33 / 100$ lower when compared to the reference. For the third semester, the difference was $-0.01 / 100=-0.0001$, a minimal difference. That is, based on these estimates, there was a minimal difference, possibly non-significant, between the current policy and the simulation without any affirmative action policy for results beyond the first semester. When we compare the previous policy with the current one, we observe that the latter showed better results, and both showed that affirmative action policy beneficiaries catch up with non-beneficiaries during their time at the university.

Notice that some policies showed positive values, indicating that the estimated GPA was superior to the reference. These policies are all superior to the current policy in both analyzed semesters: $6.5 \%$ bonus, linear $6 \%$ bonus, $40 \%$ and $50 \%$ private/public quota, and $40 \%$ and $50 \%$ poor/non-poor quota. That is, for these policies, not only would there be an increase in the diversity of the student body when compared to the simulation with no affirmative action policy, but also there would be an increase in academic performance. Notice that the students are treated equally irrespective of the course. Thus, as the affirmative action policy can increase average academic performances while increasing the proportion of minorities at UFMG, the question should not be whether to implement affirmative action policies, but which one to choose.

Note that a trade-off between the increase in the proportion of minorities and academic performance is clear while comparing policies by type. Compare, for instance, the bonus policies of $6.5 \%, 8 \%, 10 \%$ and $12 \%$ : the larger the bonus, the lower the academic performance. We observe this same trade-off for the linear policies and each of the four types of quota. Thus, the optimum policy may take this trade-off into account; however, specific affirmative action policies are inevitably better than no policy. If the main objective of the affirmative action policy is to at least maintain academic performance while increasing the diversity of the student body, the bonus linear policy with an average bonus of $6 \%$ or the quota policy of $40 \%$ divided between students from private and public institutions are good choices.

\section{Socially optimum estimates}

This section presents the results for the socially optimum estimates. Some individuals may be more interested in increasing the proportion of minorities, while others may think that academic performance is more critical. Therefore, as described in the methodological section, we present three different estimates for indicator 1 and index $A$ and another three for indicator 2 and index $\mathrm{B}$ in order to encompass this variability: the first values the increase in the proportion of minorities twice as high as the value of the academic performance; the second values both equally; the third values academic performance twice as high as the increase in the proportion of minorities.

One policy showed better results than the current policy in all six scenarios: a quota of 50\% divided between poor and non-poor students. That is, irrespective of the main objective of the public university, whether inclusivity or academic performance is valued more highly, the current policy is a good option, but the policy quota of $50 \%$ divided between poor and non-poor students is even better.

Another policy is better than the current one in five scenarios, but not in the one most radically weighted towards an increase in the proportion of minorities: this is a quota of $50 \%$ divided between students from private and public schools. Hence, this is another good option for an affirmative action policy. Two other policies were better than the current one in four scenarios: a quota of $40 \%$ divided between poor and non-poor students; and a linear bonus with an average value of $6 \%$. This last one seems to be the best option for a bonus policy in general.

Concerning other bonus policies, many were better than the current policy for indicator 1 , but not for indicator 2 . That is, they seem to be better at equalizing opportunities and performance within each group of courses, but not across all university courses. We observed the best results among these policies for a bonus of $6.5 \%$.

\section{Conclusion}

In order to increase the proportion of minorities attending public universities in Brazil, many institutions of higher education have implemented affirmative 
action policies since the 2000s. Specifically, at UFMG, a bonus policy was implemented between the years of 2009 and 2012 (Aranha, 2009) and a quota policy has been implemented since then (Telles and Paixáo, 2013).

The main objective of this paper was to analyze 24 different counterfactual affirmative action policies at UFMG using simulations. The main that we addressed are: 1) Which affirmative action optimizes the diversity of the student body?; 2) Taking into account the potential trade-off between the increase in the proportion of minorities and academic performance, which would be the optimum policy?; 3) Bonus and quota policies differ in many aspects; which would be the optimum policy for a specific objective?

Table 8 summarizes the findings of the paper and answers these questions.

The answer to the first question depends on what characteristics are being addressed through affirmative action: race, income, public school background, or an overall function of the three. Furthermore, should the definition of equal participation depend

Table 8

\section{A General Summary of the Paper's Findings}

\begin{tabular}{|c|c|c|c|}
\hline Objective & $\begin{array}{c}\text { Taking into } \\
\text { account those } \\
\text { who apply to } \\
\text { each group of } \\
\text { courses } \\
\end{array}$ & Best policy & Best policy of different type \\
\hline \multirow{2}{*}{$\begin{array}{l}\text { Increase the } \\
\text { proportion of } \\
\text { Black/Pardo/ } \\
\text { Indigenous } \\
\text { students }\end{array}$} & Yes & $\begin{array}{l}\text { Bonus policy based on time in public } \\
\text { school - average bonus of } 7.3 \%\end{array}$ & $\begin{array}{l}\text { Quota policy of } 60 \% \text { divided between } \\
\text { poor/non-poor }\end{array}$ \\
\hline & No & $\begin{array}{l}\text { Quota policy of } 60 \% \text { divided between } \\
\text { Black/non-Black/poor/non-poor }\end{array}$ & $\begin{array}{l}\text { Bonus policy based on a linear function } \\
\text { - average bonus of } 8 \%\end{array}$ \\
\hline \multirow{2}{*}{$\begin{array}{l}\text { Increase the } \\
\text { proportion of } \\
\text { students from } \\
\text { poor households }\end{array}$} & Yes & $\begin{array}{l}\text { Bonus policy based on time in public } \\
\text { school - average bonus of } 8.7 \%\end{array}$ & $\begin{array}{l}\text { Quota policy of } 60 \% \text { divided between } \\
\text { Black/non-Black/poor/non-poor }\end{array}$ \\
\hline & No & $\begin{array}{l}\text { Quota policy of } 60 \% \text { divided between } \\
\text { Black/non-Black/poor/non-poor }\end{array}$ & $\begin{array}{l}\text { Equal bonus policy - average bonus of } \\
12 \%\end{array}$ \\
\hline \multirow{2}{*}{$\begin{array}{l}\text { Increase the } \\
\text { proportion of } \\
\text { students from } \\
\text { public secondary } \\
\text { schools }\end{array}$} & Yes & Equal bonus policy - average bonus of $8 \%$ & $\begin{array}{l}\text { Quota policy of } 60 \% \text { divided between } \\
\text { students from private/public schools }\end{array}$ \\
\hline & No & $\begin{array}{l}\text { Quota policy of } 40 \% \text { divided between } \\
\text { Black/non-Black/poor/non-poor }\end{array}$ & $\begin{array}{l}\text { Bonus policy }-5 \% \text { for students from } \\
\text { public schools and } 7 \% \text { for Black/ } \\
\text { Pardos/Indigenous from public schools }\end{array}$ \\
\hline \multirow{2}{*}{$\begin{array}{l}\text { Increase the } \\
\text { proportion of } \\
\text { minorities }\end{array}$} & Yes & $\begin{array}{l}\text { Equal bonus policy - average bonus of } \\
10 \%\end{array}$ & $\begin{array}{l}\text { Quota policy of } 60 \% \text { divided between } \\
\text { poor/non-poor }\end{array}$ \\
\hline & No & $\begin{array}{l}\text { Quota policy of } 50 \% \text { divided between } \\
\text { Black/non-Black/poor/non-poor }\end{array}$ & $\begin{array}{l}\text { Bonus policy based on a linear function } \\
\text { - average bonus of } 6 \%\end{array}$ \\
\hline \multirow{2}{*}{$\begin{array}{l}\text { Socially optimum } \\
\text { - minority } \\
\text { inclusion first }\end{array}$} & Yes & $\begin{array}{l}\text { Equal bonus policy - average bonus } \\
\text { of } 10 \% \text {; Quota policy of } 60 \% \text { divided } \\
\text { between poor/non-poor }\end{array}$ & - \\
\hline & No & $\begin{array}{l}\text { Quota policy of } 50 \% \text { divided between } \\
\text { poor/non-poor }\end{array}$ & $\begin{array}{l}\text { Bonus policy based on a linear function } \\
\text { - average bonus of } 6 \%\end{array}$ \\
\hline \multirow{2}{*}{$\begin{array}{l}\text { Socially optimum } \\
\text { - equal weights }\end{array}$} & Yes & $\begin{array}{l}\text { Bonus policy based on a linear function } \\
\text { - average bonus of } 6 \%\end{array}$ & $\begin{array}{l}\text { Quota policy of } 60 \% \text { divided between } \\
\text { poor/non-poor }\end{array}$ \\
\hline & No & $\begin{array}{l}\text { Quota policy of } 50 \% \text { divided between } \\
\text { poor/non-poor }\end{array}$ & $\begin{array}{l}\text { Bonus policy based on a linear function } \\
\text { - average bonus of } 6 \%\end{array}$ \\
\hline \multirow{2}{*}{$\begin{array}{l}\text { Socially optimum } \\
\text { - academic } \\
\text { performance first }\end{array}$} & Yes & $\begin{array}{l}\text { Bonus policy based on a linear function } \\
\text { - average bonus of } 6 \%\end{array}$ & $\begin{array}{l}\text { Quota policy of } 60 \% \text { divided between } \\
\text { poor/non-poor }\end{array}$ \\
\hline & No & $\begin{array}{l}\text { Quota policy of } 40 \% \text { divided in poor/ } \\
\text { non-poor }\end{array}$ & $\begin{array}{l}\text { Bonus policy based on a linear function } \\
\text { - average bonus of } 6 \%\end{array}$ \\
\hline
\end{tabular}


on the heterogeneity of the applicants, or should it be independent of it? If we do not take into account this heterogeneity, the current policy, a quota of $50 \%$ divided among four groups, is well-designed. If we do take this heterogeneity of the applicants into account, a bonus policy would be the best option. However, we presented different policies as the best options in each of the different scenarios, and no bonus policy seems much superior to the others. Another right choice is the quota policy of $60 \%$ divided between poor and non-poor students.

Nonetheless, if we also take into account academic performance, conclusions are more straightforward. If an overall increase in the proportion of minorities is sought, the best choice would be the quota policy of $50 \%$ divided between poor and non-poor students. When we take into account the heterogeneity of the applicants, the best choice would be the bonus policy based on the linear function with a average bonus of $6 \%$. These options could replace the current policy without loss and with gain.

\section{REFERENCES}

ARANHA. Antônia. (2009), "Bônus sociorracial na UFMG: vitória da inclusão e da democracia”. Boletim, Belo Horizonte: Universidade Federal de Minas Gerais (publicação semanal), 1639.

ARANHA, Antônia, PENA, Carolina \& RIBEIRO, Sergio. (2012), "Programas de inclusão na UFMG: o efeito do bônus e do reuni nos quarto primeiros anos de vigência - um estudo sobre acesso e permanência”. Educação em Revista, 28, 04: 317-345.

ARAÚJO, Fernando \& SIQUEIRA, Liedge. (2010), "Determinantes do desempenho escolar dos alunos da $4^{a}$ série do ensino fundamental no Brasil". Economia e Desenvolvimento, 9, 1.

ASTIN, Alexander \& OSEGUERA, Leticia. (2004), "The declining 'equity' of American higher education." The Review of Higher Education, 27, 3: 321-341.

BAI, Chong-en \& CHI, Wei. (2011), “Determinants of undergraduate GPAs in China: college entrance examination scores, high school achievement and admission route." MPRA.[S.1.], 5, 1: 1-27.

BARROS, Ricardo, MENDONÇA, Rosana, SANTOS, Daniel \& QUINTÁES, Giovani. (2001), "Determinantes do desempenho educacional do Brasil". Pesquisa e Planejamento Econômico, 31, 1: 1-42.

BETTINGER, Eric, EVANS, Brent \& POPE, Devin. (2013), "Improving college performance and retention the easy way: unpacking the ACT exam." American Economic Journal: Economic Policy, 5, 2: 26-52.

BEZERRA, Teresa \& GURGEL, Claudio. (2011), "A política pública de cotas em universidades. desempenho acadêmico e inclusão social”. Sustainable Business International Journal, 9.

BUDDELMEYER, Hielke \& SKOUFIAS, Emmanuel. (2004), "An Evaluation of the Performance of Regression Discontinuity Design on PROGRESA.” World Bank Policy Research Working Paper, 3386.

BULMAN, George. (2017), "Weighting recent performance to improve college and labor market outcomes." Journal of Public Economics, 146: 97-108.

CAVALCANTI, Ivanessa, ANDRADE, Cláudia, TIRYAKI, Gisele, \& COSTA, Lilia. (2019), "Desempenho acadêmico e o Sistema de cotas no ensino superior: evidência empírica com dados da Universidade Federal da Bahia”. Avaliação (Campinas), 24, 1: 305-327.

LEE, David \& LEMIEUX, Thomas. (2010), "Regression Discontinuity Designs in Economics." Journal of Economic Literature, 48, 2: 281-355.

EPPLE, Dennis, ROMANO, Richard \& SIEG, Holger. (2008), "Diversity and Affirmative Action in Higher Education." Journal of Public Economic Theory, 10, 4: 475-501.

FRANCIS, Andrew \& TANNURI-PIANTO, Maria. (2012), "Using Brazil's racial continuum to examine the short-term effects of affirmative action in higher education." Journal of Human Resources, 47, 3: 754-784.

FREITAS, Marcus. (2006), "Haverá cotas na UFMG?" In: Boletim (publicação semanal da Universidade Federal de Minas Gerais). Disponível em http:// www.ufmg.br/boletim/bol1535/segunda.shtml. 
FRYER JR, Roland, LOURY, Glen \& YURET, Tolga. (2008), "An Economic Analysis of Color-Blind Affirmative Action." Journal of Law Economics and Organization, 24, 2: 319-355.

GOLGHER, André, AMARAL, Ernesto, \& NEVES, Alan. (2014), "Avaliação de impacto do bônus sociorracial da UFMG no desempenho acadêmico dos estudantes". Mediaçôes - Revista de Ciências Sociais, 19,1 .

GOLGHER, André, AMARAL, Ernesto, \& NEVES, Alan. (2015), "Desempenho acadêmico dos estudantes da UFMG: uma análise da política de bônus sociorracial". Ciências Sociais em Perspectiva. 14: 120-145.

GUARNIERI, Fernanda, \& MELO-SILVA, Lucy. (2017), "Cotas universitárias no Brasil: Análise de uma década de produção científica". Psicologia Escolar e Educacional, 21, 2: 183-193.

GUIMARÃES, Antônio. (2010), "Colour and Race in Brazil: from whitening to the search for Afrodescent." XVII ISA World Congress of Sociology, Gothenburg.

HOLZER, Harry \& NEUMARK, David. (2006), "Affirmative action: What do we know?" Journal of Policy Analysis and Management, 25, 2: 463-490.

JACCOUD, Luciana \& BEGHIN, Nathalie. (2002), Desigualdades raciais no Brasil: um balanço da intervenção governamental. Brasília: IPEA.

KLEINKE, Mauricio. (2006), "O Vestibular Unicamp e a Inclusão Social: Experiências e Perspectivas". Campinas: Comissão Permanente de Vestibulares (mimeo).

LIMA, Edileusa \& MACHADO, Lucilia. (2016), "Reuni e Expansão universitária na UFMG de 2008 a 2012". Educação e realidade, 41, 2: 383-406.

LOURY, Linda \& GARMAN, David. (1993), "Affirmative action in higher education." American Economic Review, 83, 2: 99-103.

MENDES JUNIOR, Alvaro. (2014), “Uma análise da progressão dos alunos cotistas sob a primeira ação afirmativa brasileira no ensino superior: o caso da Universidade do Estado do Rio de Janeiro". Ensaio: Avaliação e Políticas Públicas em Educação, 22, 82: 31-56.
PEDROSA, Renato, DACHS, Norberto, MAIA, Rafael \& ANDRADE, Cibele. (2007), "Academic performance, students' background and affirmative action at a Brazilian university." Higher Education Management and Policy, 19, 3: 1 - 20.

PEIXOTO, Maria \& BRAGA, Mauro. (2012), "Açōes afirmativas no ensino superior e o programa de bônus para ingresso nos cursos de graduaçáo da Universidade Federal de Minas Gerais". Revista Brasileira de Estudos Pedagógicos, 93, 233: 166-188. PEIXOTO, Adriano, RIBEIRO, Elisa, BITTENCOURT, Antônio \& RAMALHO, Maria. (2016), "Cotas e desempenho acadêmico na UFBA: um estudo a partir dos coeficientes de rendimento". Avaliação: Revista da Avaliação da Educação Superior, 21, 2: 569-591.

PIOTTO, Debora \& NOGUEIRA, Maria. (2016), "Incluindo quem? Um exame de indicadores socioeconômicos do Programa de Inclusão Social da USP”. Educação e Pesquisa, 42, 3: 625-649.

QUEIROZ, Cristina, MIRANDA, Gilberto, TAVARES, Marcelo, FREITAS, Sheizi. (2015), "A lei de cotas na perspectiva do desempenho acadêmico na Universidade Federal de Uberlância”. Revista Brasileria de Estudos Pedagógicos, 96, 243: 299-320.

ROTHSTEIN, Jesse (2004), "College Performance Predictions and the SAT." Journal of Econometrics, 121, 1-2: 297-317.

SILVA, Nelson \& HASENBALG, Carlos. (2002), "Recursos Familiares e Transiçōes Educacionais". Cadernos de Saúde Pública, 18, suplemento: 67-76.

SIMAN, Ângela. (2005), Politicas públicas: a implementação como objeto de reflexão teórica e como desafio prático. Tese (Doutorado em Sociologia e Política) - UFMG, Belo Horizonte.

SOARES, José \& ALVES, Maria. (2013), "Effects of schools and municipalities in the quality of basic education". Cadernos de Pesquisa, 43, 149.

TELLES, Edward \& PAIXÃO, Marcelo. (2013), "Affirmative action in Brazil." LASAFORUM, $14,2$.

TOSTA, Sandra, \& ALVES, Pollyana. (2013), "Identidade negra e condiçẫo de classe - construçôes indentiárias de adoslecentes negros de elite emu 
ma escola privada de Belo Horizonte - MG”. Ponto Urbe, 13.

VELLOSO, Jacques. (2009), "Cotistas e não-cotistas: rendimento de alunos da Universidade de Brasilia". Cadernos de Pesquisa, 39, 137: 621-644.
VIGNOLES, Anna \& POWDTHAVEE, Nattavudh. (2009) "The socioeconomic gap in university dropouts." B.E. Journal of Economic Analysis and Policy: Topics in Economic Analysis and Policy, 9(1). 


\section{COMPARISONS OF COUNTERFACTUAL AFFIRMATIVE ACTION POLICIES AT THE FEDERAL UNIVERSITY OF MINAS GERAIS}

\section{André Braz Golgher}

Keywords: minorities, affirmative action policies, bonus, quotas, UFMG.

Tertiary education attendance in Brazil varies remarkably among different population groups. In order to decrease inequalities and increase the proportion of minorities in public universities, many institutions of higher education in Brazil have implemented affirmative action policies since the 2000s. The main objective of this paper was to analyze different counterfactual affirmative action policies at the Federal University of Minas Gerais (UFMG) based on simulations, measuring the proportion of minorities and the level of academic performance at this institution under each scenario. The current quota policy of $50 \%$ for students from public secondary schools, divided between four main groups (non-poor/non-minority; poor/non-minority; non-poor/minority; poor/minority), was shown to be well-designed to promote higher proportions of minorities among the student body. However, if academic performance is also taken into account, the best options would be either a quota policy of 50\% divided between poor and nonpoor students or a bonus policy based on a linear function of course competitiveness with an average bonus of $6 \%$.

\section{COMPARAÇÓES DE POLÍTICAS DE AÇÓES AFIRMATIVAS SIMULADAS NA UNIVERSIDADE FEDERAL DE MINAS GERAIS}

\section{André Braz Golgher}

Palavras-chave: Minorias, Políticas de ação afirmativa, Bônus, Cotas, UFMG

A proporção de indivíduos que frequenta a educação superior no Brasil varia de forma marcante entre os diferentes grupos da população. Como forma de diminuir a desigualdade no acesso à educaçáo superior e aumentar a proporção de minorias na universidade públicas, muitas instituiçóes de nível superior no Brasil implementaram políticas de ação afirmativa a partir de 2000. O objetivo principal desse artigo é analisar políticas contrafactuais de ação afirmativa na Universidade Federal de Minas Gerais (UFMG), a partir de simulaçóes que mediram a proporção de minorias e o desempenho acadêmico nessa instituição. A atual política de 50\% de cotas para estudantes do ensino médio público dividida em quatro grupos principais (não pobre/não negro; pobre/não negro; não pobre/negro; pobre/negro) se mostrou eficaz para promover a inclusão de maiores proporçôes de minorias na universidade. Entretanto, se o desempenho acadêmico é levado em conta, as melhores escolhas de políticas afirmativas seriam uma política de cotas de 50\%, dividida entre pobres e não pobres, ou uma política de bônus baseada em uma função linear da competitividade do curso com bônus médio de 6\%.

\section{COMPARAISONS DE POLITIQUES D'ACTIONS POSITIVES SIMULÉES À L'UNIVERSITÉ FÉDÉRALE DE MINAS GERAIS}

\section{André Braz Golgher}

Mots-clés: minorités; politique d'action affirmative; bonus; quotas; UFMG.

Le nombre de personnes fréquentant l'enseignement supérieur au Brésil varie considérablement selon les groupes de la population. Afin de réduire les inégalités et d'augmenter le taux des minorités dans les universités publiques, de nombreux établissements d'enseignement supérieur ont mis en œuvre des politiques d'action positive depuis les années 2000. L'objectif principal de cet article est d'analyser les politiques d'action positive contrefactuelles à l'Université Fédérale de l'état de Minas Gerais (UFMG) sur la base de simulations qui mesurent le taux de minorités et la performance universitaire dans cette institution. En réservant $50 \%$ des places dans les universités fédérales aux élèves des écoles secondaires publiques, divisés en quatre groupes principaux (non pauvres/non minoritaires; pauvres/non minoritaires; non pauvres/minoritaires; pauvres/minoritaires), la politique actuelle s'est avérée efficace pour promouvoir l'inclusion d'un plus grand nombre d'étudiants issus des minorités. Mais si la performance universitaire est prise en compte, tout indique que les politiques affirmatives les plus pertinentes seraient soit une politique de quotas de $50 \%$ répartie entre étudiants pauvres et non pauvres, soit une politique de bonus basée sur une fonction linéaire de la compétitivité des cours avec un bonus moyen de 6\%. 